\title{
PERANAN BADAN PENYELIDIK USAHA-USAHA PERSIAPAN KEMERDEKAAN INDONESIA (BPUPKI) 1945 DALAM PROSES MENUJU KEMERDEKAAN INDONESIA
}

\author{
Nana Setialaksana ${ }^{1}$ \\ Dosen Universitas Siliwangi (UNSIL) \\ Jl. Siliwangi No. 24 Kota Tasikmalaya 46115 Jawa Barat
}

\begin{abstract}
ABSTRAK
Tujuan pembentukan BPUPKI oleh pemerintah Jepang, yaitu hanya menyelidiki usaha-usaha persiapan kemerdekaan namun kenyataan sebenarnya ialah "Merancang Undang Undang Dasar Indonesia yang merdeka dan berdaulat". Kiranya dapat dipahami bahwa BPUPKI yang mewakili seluruh bangsa Indonesia benar-benar mengambil nasibnya ditangan sendiri untuk menentukan persiapan kemerdekaannya, artinya tidak menurut saja kepada ketentuan Juridis formil dan keinginan kolonialis Jepang. Metode yang penulis gunakan dalam penelitian ini adalah suatu penelitian yang bersifat mejelajah. Karena yang diteliti adalah suatu masalah yang terjadi di masa lampau, penulis mempergunakan metode penelitian historis.. Metode penelitian historis adalah suatu metode untuk membuat rekonstruksi masa lampau secara sistematis dan objektifitas, dengan cara mengumpulkan, mengevaluasi, memverifikasikan, mensintesiskan bukti-bukti untuk menegakan fakta dan memperoleh kesimpulan yang kuat.
\end{abstract}

Kata Kunci: BPUPK dan BPUPKI

\begin{abstract}
The aim of Japan Government to establish the BPUPKI is not only to investigate the efforts of liberating Indonesia, but also "To Arrange an Independent Indonesia's Constitution". It is realized that BPUPKI which are represent the whole of Indonesian as the determinant in preparing Indonesia's liberation. It means, they should decided it by themselves not according to Japan Colonialist's desire or formal juridical decision. The research tends to exploration research since the object of the research is an issue which is happened in past time and historical research is used as the method of the research. Historical research method is a method to arrange the past time reconstruction systematically and objectively by collecting, evaluating, verifying, and synthesize the evidences to obtain a clear fact and a strong conclusion.
\end{abstract}

\section{Keywords: BPUPK and BPUPKI}

\section{PENDAHULUAN}

Pemerintahan Kolonial Belanda di Indonesia berakhir ketika Perang Dunia II digantikan oleh kekuasaan pemerintahan militer Jepang yang mengaku dirinya "Pemimpin Asia dan Saudara Tua bangsa Indonesia", namun kenyataannya, dalam lapangan politik pemerintah Jepang itu tiada bedanya dengan penjajahan lainnya yang selalu menekan cita-cita kemerdekaan bangsa Indonesia. Kemudian di dalam perlawanan terhadap Sekutu (barat) makin lama makin terdesak dan mendapat kekalahan-kekalahan, maka Pemerintahan

\footnotetext{
${ }^{1}$ Penulis Koresponden

E-mail address: setianana@yahoo.com doi: http://dx.doi.org/10.25157/ja.v4i2.904
}

Jepang terpaksa bersiasat "murah hati" dengan cara menjanjikan kemerdekaan untuk menarik hati bangsa Indonesia, Pemerintah Jepang membentuk Panitia Pemeriksa Adat dan Tata Negara dengan tugas menyelidiki adat dan tata negara Indonesia lama untuk disumbangkan kepada Jepang.

Pada tanggal 7 September 1944 di dalam sidang istimewa ke-85 Teikoku Ginkai (Parlemen Jepang) di Tokyo, Perdana Menteri Koiso (pengganti Perdana Menteri Tojo) mengumumkan tentang pendirian pemerintah Kemaharajaan Jepang, bahwa daerah Hindia Timur (Indonesia) diperkenankan merdeka kelak

Copyright@2017 Jurnal Artefak e-ISSN: 2580-0027 
dikemudian hari. Latar belakang dikeluarkannya pernyataan tersebut, karena semakin terdesaknya angkatan perang Jepang (Marwatidjoened Poesponegoro, 1990:66).

Pada tanggal 1 Maret 1945 Pemerintahan Jepang mengumumkan pembentukan Badan Penyelidik Usaha-usaha Persiapan Kemerdekaan Indonesia (Dokuritsu Zyumbi Tyoosakai). Ini merupakan suatu langkah pertama bagi pelaksanaan janji kemerdekaan Indonesia di kemudian hari.

\section{METODE PENELITIAN}

Metode yang penulis gunakan dalam penelitian ini adalah suatu penelitian yang bersifat mejelajah. Karena yang diteliti adalah suatu masalah yang terjadi di masa lampau, penulis mempergunakan metode penelitian historis.. Metode penelitian historis adalah suatu metode untuk membuat rekonstruksi masa lampau secara sistematis dan objektifitas, dengan cara mengumpulkan, mengevaluasi, memverifikasikan, mensintesiskan bukti-bukti untuk menegakan fakta dan memperoleh kesimpulan yang kuat.

\section{HASIL PENELITIAN DAN PEMBAHASAN}

\section{Pembentukan BPUPKI}

BPUPKI (Dokuritsu Zyumbi Tyoosakai) yang dibentuk tanggal 29 April 1945, belum dapat melaksanakan tugasnya karena belum ada pelantikan para anggota secara resmi oleh pemerintah Jepang. Persiapan-persiapan untuk pelaksanaan sidang Badan Penyelidik terus dilakukan. Sebagai tempat persidangan ditetapkan di Gedung Volksraad, yaitu suatu bangunan bergaya klasik Yunani-Romawi yang terletak di Pejambon. Gedung itu sebelumnya dipergunakan untuk sidang-sidang Perwakilan Rakyat di jaman Belanda (Moh. Ridhwan Indra, 1987:41).

Hari Minggu tanggal 27 Mei 1945 jam 10.30 semua anggota Badan Penyelidik beserta anggota istimewa sudah hadir dengan pakaian rapi di Gumseikanbu (Kantor Gunseikan yang sekarang ditempati oleh Pertamina di jalan Perwira No. 2 Jakarta Pusat). Setelah Gunseikan tiba, upacara segera dimulai, Gunseikan sebagai kepala pemerintahan sipil di Jawa menerima laporan tentang persiapan untuk menyelenggarakan sidang Badan Penyelidik.
Laporan pertama dilakukan oleh Ichibangase, wakil ketua (ketua muda) Badan Penyelidik dan anggota istimewa. Dilaporkan bahwa, semua anggota istimewa Badan Penyelidik telah siap untuk kepentingan persidangan Badan Penyelidik.

Kemudian menyusul giliran ketua Badan Penyelidik K.R.T. Radjiman Wediodiningrat yang melaporkan bahwa, anggota Badan Penyelidik telah hadir dan siap untuk melaksanakan segala tugas yang dibebankan kepada Badan Penyelidik. Juga dilaporkan segala sesuatunya yang diperlukan dan disiapkan untuk keperluan sidang Badan Penyelidik (Nugroho N, 1971 : 28). Tanggal 27 Mei 1945 itu, boleh dikatakan merupakan gladi bersih untuk persiapan pelantikan anggota Badan Penyelidik yang akan dilaksanakan keesokan harinya pada tanggal 28 Mei 1945. Sidang Badan Penyelidik itu adalah merupakan sidang yang berat, penuh resiko, karena sidang tersebut menyangkut kelanjutan nasib bangsa Indonesia di kemudian hari apabila tercapai cita-cita kemerdekaan.

Besok paginya, yaitu tanggal 28 Mei 1945, jam 10.00, anggota Badan Penyelidik dan anggota istimewa dari bangsa Jepang sudah hadir di Gedung Tyoo Sangi Iin. Mereka berkumpul mengadakan upacara pengibaran Sang Saka Merah-Putih bersama-sama dengan bendera dari kebangsaan Jepang Hiromaru (Matahari terbit). Selanjutnya, bendera kebangsaan Indonesia Merah-Putih boleh dikibarkan di tempat-tempat resmi disamping bendera Hiromaru. Upacaranya sederhana tapi penuh hidmat dan mengharukan.

Anggota Badan Penyelidik dan para undangan lainnya sudah hadir pada jam 14.15 di Gedung Tyoo Sangi Iin. Pembesar-pembesar yang hadir dalam pelantikan itu adalah : Saiko Sikikan, Gunseikan, para pembesar dari Gunseikanbu, Soomubutyo (semacam sekretaris negara), perwira-perwira tinggi Bala tentara Jepang, ketua muda Tyoo Sangi Iin R.A.A. Kusumo Utojo, dan lain-lain.

\section{Sidang BPUPK}

Permulaan sidang pertama pada tanggal 29 Mei 1945 dibuka oleh Ketua Badan Penyelidik Dr. Radjiman Wediodiningrat (Ismaun, 1978 : 113). Yang bertindak sebagai pembicara pada tanggal 29 Mei 1945 antara lain: Muhammad Yamin, Margono, Sastrodiningrat, Wiranatakoesoemah, Soemitro, Woerjoningrat, Soerjo, Dasaad, Soesanto, Roseno, dan lain-lain. 
Sedangkan pada tanggal 30 Mei 1945 tercatat bertindak sebagai pembicara antara lain : Moh. Hatta, H. Agoes Salim, Samsoedin, Wongsonegoro, Abdoel Kadir, Soerachman, Soewandi, Abdoel Rahim, Soetardjo, dan Soekiman. Pada tanggal 31 Mei 1945 tercatat sebagai pembicara : Muh. Yamin, Sanusi, Subarjo, Soekarno, Hadikoesoemo, dan pada tanggal 1 Juni 1945 tercatat Kaswedan, Moezzakir, Soekarno, Latoeharhary dan Soekardjo.

Selanjutnya hasil sidang Badan Penyelidik disebarluaskan kedaerah-daerah melalui utusan-utusan yang ditugaskan ke daerah untuk menjelaskan hasil-hasil yang diperoleh selama persidangan pertama Badan Penyelidik yaitu dari tanggal 29 Mei s/d 1 Juni 1945.

Dalam hal itu bahwa, yang menonjol dalam persidangan ialah perasaan kesatuan antara sesama anggota Badan Penyelidik, dan semua anggota memahami azas dan bentuk negara yang akan dibentuk dalam negara Indonesia itu nanti. Pada sidang pertama Badan Penyelidik, telah dibahas mengenai hal yang mendasar secara mendalam berkenaan dengan dasar-dasar Indonesia Merdeka. Selama masa sidang pertama terdapat tiga orang pembicara yang menonjol mengemukakan pandanganpandangan mereka tentang dasar-dasar negara Indonesia merdeka, yaitu terdiri dari:

1) Mr. Muhammad Yamin, menyampaikan pidatonya pada tanggal 29 Mei 1945 berjudul "Azas dan Dasar Negara Indonesia Merdeka".

2) Prof. Dr. Mr. R. Soepomo menyampaikan pidatonya pada tanggal 31 Mei 1945, tentang masalah "Dasardasarnya Negara Indonesia Merdeka".

3) Ir. Soekarno, menyampaikan pidatonya pada tanggal 1 Juni 1945 tentang "Dasar Indonesia Merdeka", (Muhammad Yamin, $1945:$ 123).

Selain itu, Mr. Muhammad Yamin menyampaikan lagi pidatonya pada tanggal 31 Mei 1945 mengenai "Daerah Negara Indonesia. Pidato-pidato dari anggota lain tidak mengetengahkan tentang masalah dasar-dasar secara terperinci, misalnya Drs. Moh. Hattta hanya menyampaikan pidatonya mengenai Ekonomi pada tanggal 30 Mei 1945, teks pidato Moh. Hatta tidak dapat diketahui lagi dimana kini, hanya pada pokoknya Moh. Hatta mengetengahkan pernyataan mengenai sistem
Ekonomi Sosialis atau sistem ekonomi yang berkeadilan sosial. Sedangkan pidato dari ketiga tokoh diatas merupakan tanggapan langsung atas "tantangan" dari pidato Ketua Badan Penyelidik Dr. Radjiman Wediodiningrat mengenai "Indonesia Merdeka apa dasarnya ?". (Moh. Ridwan Indra, 1987 : 54).

Mr. Muh.Yamin pada tanggal 29 Mei 1945 menyampaikan prasaran / usul yang disiapkan secara tertulis lebih dahulu dengan judul "Azas dan Dasar Negara Kebangsaan Republik Indonesia". (Mr. Muh. Yamin, 1959 : 87) yang terdiri dari lima dasar dan azas yaitu, peri kebangsaan, peri kemanusiaan, peri ketuhanan, peri kerakyatan, dan kesejahteraan rakyat/keadilan sosial (Muh. Yamin, 1959 : 8788). Pidato Muh. Yamin pada tanggal 29 mei 1945 selain menyinggung tentang dasar negara, status warga negara keturunan seperti peranakan Arab, Cina, sehingga untuk hal tersebut Wakil Ketua RP. Soeroso menginterupsi pidato Yamin agar perihal warga negara tersebut dibicarakan lain waktu saja. Sehingga terjadilah sedikit perdebatan antara Muh. Yamin dengan Wakil Ketua RP. Soeroso.

Sementara itu golongan Islam, antara lain K.H. Wahid Hasjim, Ki Bagoes Hadikoesoemo, H. Agoes Salim, K.H. Abdoel Kahar Moezzakir, dalam sidang BPUPKI mengusulkan konsepsi, agar Dasar Negara Indonesia Merdeka adalah Islam. Usul dari konsepsi itupun tidak mendapat kesepakatan dari sidang. Pada tanggal 31 Mei 1945 yang berpidato pertama ialah Prof. Dr. Mr.R. Soepomo mengemukakan tentang teori negara juridis, politis dan sosiologis, syaratsyarat berdirinya negara, bentuk negara dan bentuk pemerintahan serta hubungan antara negara dengan agama. Sebagai pembicara kedua ialah Mr. Muhammad Yamin yang menguraikan tentang Dasar Negara-Kebangsaan Indonesia atas dasar tinjauan juridis, historis, politis, sosiologis, geografis dan konstitusional yang meliputi seluruh Nusantara.

Pokok-pokok pidato Prof. Dr. Mr. R. Soepomo itu membicarakan mengenai syarat mutlak dan adanya suatu negara terutama adanya faktor konstitutif, baik dari sudut hukum maupun dari sudut formal. Soepomo mengatakan adanya suatu negara harus ada suatu daerah (territority) rakyat dan harus ada pemerintah yang berdaulat (souvereign) sebagaimana syarat-syatat yang dikeluarkan oleh hukum internasional.

Selain itu Soepomo mengemukakan masalah mengenai staat idea, maka untuk itu Soepomo telah memaparkan tentang teori-teori 
ilmu negara yang ada di dunia, disinggungnya mengenai teori perorangan, yaitu negara terdiri atas dasar, teori perseorangan, teori individualis, seperti yang diajarkan oleh Thomas Hobbes dan John Locke pada abad ke 17, Jean Jacques Rousseu abad ke 18, Hebert Spancer abad 19, H.J. Laski abad ke 20. Menurut aliran ini negara ialah masyarakat hukum (legal society) yang disusun atas kontrak seluruh individu dalam masyarakat itulah yang disebut "Contract Social".

Disinggung pula mengenai teori negara dari teori golongan (Classtheory) sebagai yang diajarkan oleh Marx, Engels dan Lenin yang mengatakan, bahwa negara sebagai alat dari suatu golongan untuk menindas golongan yang lain. Dikemukakan pula aliran pikiran lain lagi pengertian negara ialah teori yang dinamakan teori integralistik, yang diajarkan oleh Sinoza, Adam Muller, Hegel dan lain-lain abad 18 dan 19. Menurut pikiran ini, negara ialah tidak untuk menjamin kepentingan seseorang atau golongan, akan tetapi menjamin kepentingan masyarakat seluruhnya sebagai persatuan.

Negara ialah susunan masyarakat yang integral. Segala golongan, segala bagian, segala anggotanya berhubungan erat satu sama lain dan merupakan persatuan masyarakat yang organis, yang terpenting dalam negara yang berdasarkan aliran pikiran integral ialah penghidupan bangsa seluruhnya. Negara tidak memihak sesuatu golongan yang kuat, atau yang paling besar, tidak menganggap kepentingan seseorang sebagai pusat akan tetapi negara menjamin keselamatan hidup bangsa seluruhnya sebagai persatuan yang tidak dapat dipisah-pisahkan. Pembangunan negara bersifat barang yang bernyawa. Karenanya corak dan bentuknya harus disesuaikan dengan keadaan umum pada masa sekarang dan harus mempunyai keistimewaan yang sesuai dengan keadaan umum tadi. Janganlah kita meniru belaka susunan negara lain (Muh. Yamin, 1959 L 110111). Soepomo menyimpulkan bahwa, negara yang cocok dengan bentuk negara yang akan didirikan sebagai negara Indonesia merdeka adalah negara yang integralistik.

Pada tanggal 1 Juni 1945, sidang Badan Penyelidik belum memperoleh kesepakatan yang dimaksudkan oleh ketua sidang, padahal sidang sudah berlangsung tiga hari sejak tanggal 29 Mei 1945, maka pada gilirannya, Ir. Soekarno berpidato untuk mengemukakan pendapatnya secara lisan tanpa teks. Pidato itu dicatat secara stenograf oleh Notulis. Dalam pidatonya, Ir.
Soekarno mula-mula mengemukakan tentang adanya pemikiran yang "Zwaarwichtig", membicarakan hal-hal sekecil-kecilnya atau jelimet yang mengajak hadirin untuk permintaan ketua sidang, yaitu mencari dasar negara Indonesia Merdeka, untuk itu terlebih dahulu perlu beliau mengajak sejarah lahirnya negaranegara di dunia dan membandingbandingkannya satu sama lainnya bahwa timbulnya dan isi negara itu berbeda-beda sesuai dengan keadaan bangsa masing-masing.

Oleh karena itu, Bung Karno dengan tandas mengemukakan terlebih dahulu tentang arti dan sangat pentingnya kita medeka terlebih dahulu, Bung Karno dalam pidatonya mengatakan: “......bahwa kemerdekaan, politieke orafhankelijkheid, political indefendence ta'lain dan ta'bukan adalah suatu jembatan, satu jembatan emas ...". (Muh. Yamin 1959: 62-63).

Menurut beliau Merdeka artinya adalah political, indefendence atau politiche orafhandkelijkheid yaitu kemerdekaan politik. Dianjurkan bahwa kita harus berani merdeka sekarang ini juga karena kemerdekaan itu merupakan jembatan emas, dan diseberangnya kita membangun untuk menyempurnakan masyarakat dan negara, kita bangun dalam segala bidang kehidupan. Selanjutnya Bung Karno memberikan contoh-contoh, bahwa hampir semua negara yang timbul dan ada di dunia ini didirikan atas dasar suatu cita-cita filsafat atau weltan schaung tertentu, misalnya Saudi Arabia atas dasar Islam, Uni Soviet atas dasar komunisme, Amerika Serikat atas dasar liberalism, Jerman-Hitler atas dasar nazisme, Tiongkok Nasionalisme atas dasar Sun Min Chui dan sebagainya.

Kemudian beliau juga mengajak kepada anggota sidang "Kita bersama-sama mencari persatuan philosophische grondslag, mencari satu Weltanschaung yang kita semuanya setuju". (Muh. Yamin, 1959 : 68). Bahwa kita mencari suatu modus, bukan konpromi, yang kita samasama setuju karena kita hendak mendirikan Negara Indonesia Merdeka bukan untuk satu orang atau bukan untuk satu golongan, melainkan hendak mendirikan suatu negara semua buat semua.

Dasar yang baik untuk Negara Indonesia adalah kemerdekaan, tidak meniru Amerika, Rusia, Saudi Arabia mapun Tiongkok tetapi kita mendirikan negara atas dasar suatu cita-cita sendiri atas dasar kepribadian bangsa kita sendiri. Kemudian Bung karno mengemukakan 
pendapatnya apa yang diminta oleh ketua sidang, yaitu "Philosofische gronslag" fondemen, filsafat pikiran yang sedalam-dalamnya, jiwa, hasrat yang sedalam-dalamnya untuk diatasnya didirikan Gedung Indonesia Merdeka kekal abadi (Muh. Yamin, 1959 : 61).

Bung Karno mengajak semuanya: "Marilah kita mengamalkan, jalankan agama, baik Islam maupun Kristen dengan cara berkeadaban. Artinya adalah hormat menghormati satu sama lain, toleransi, saling menghormati agama masing-masing maupun agama orang lain, sebagaimana telah diberi suri tauladan oleh Nabi Muhammad maupun Nabi Isa”. Disinilah, dalam pengakuan azas yang kelima segenap agama yang ada di Indonesia sekarang ini akan mendapat tempat yang sebaikbaiknya. Dan negara kita akan ber-Tuhan pula. Dasar negara yang telah dikemukakan sebagai usul Bung karno kepada sidang BPUPKI tersebut di atas yang terdiri dari lima azas atau prinsip itu diberi nama Pancasila yang berisi lima azas pokok fundamental yang merupakan satu rangkaian kesatuan yang bulat, yaitu:

1) Kebangsaan Indonesia,

2) Internsionalisme atau perikemanusiaan,

3) Mufakat atau demokrasi,

4) Kesejahteraan social, dan

5) Ke-Tuhanan Yang Maha Esa. (Ismaun, $1978: 157)$

Panca artinya lima dan sila artinya azas atau dasar. Di atas kelima dasar itulah kita mendirikan Negara Indonesia yang kekal dan abadi. Nama Pancasila itu dipergunakan dan beliau usulkan menurut petunjuk seorang teman beliau, seorang ahli bahasa (yang dimaksudkan hadir sebagai anggota BPUPKI dan duduk di sebelah kanan Bung Karno, yakni Mr. Muh. Yamin). Pancadharma tidak tepat digunakan, karena "Dharma" artinya "Kewajiban" sedangkan sidang waktu itu memang hendak mencari dasar Indonesia Merdeka.

Walaupun dasar Pancasila itu sudah menjadi keyakinan pribadi Bung Karno untuk dijadikan falsafah Negara Indonesia Merdeka, namun pada waktu itu beliau terlebih dahulu kepada hadirin menawarkan untuk mempersilahkan memilih bilangan azas/dasar negara yang dusepakati bersama. Selanjutnya Bung Karno mengemukakan usul alternatifnya bahwa Pancasila boleh diperas sehingga tinggal tiga saja.

Dua dasar yang pertama, yaitu internasionalisme dan kebangsaan, kebangsaan dan perikemanusiaan diperas menjadi satu diberi nama socio-nationalisme.

Dasar yang berikutnya, yaitu demokrasi yang bukan demokrasi barat, tetapi politiekeconomieche democratie, yaitu politichedemocratie dengan sociale rechtuaardigheid, demokrasi denagn kesejahteraan, diperas menjadi satu dengan diberi nama SocioDemocratie. Tinggal bagi ke-Tuhanan Yang Maha Esa yang menghormati satu sama lain. Jadi yang asalnya lima, telah menjadi tiga yang beliau namakan Tri Sila yang berisi :

1) Socio-Nationalisme

2) Socio-Democratie

3) Ke-Tuhanan. (Ismaun, $1978: 159$ )

Sosio-Nationalisme, adalah gabungan sila kebangsaan dengan sila perikemanusiaan. Jadi faham Kebangsaan Indonesia adalah faham kebangsaan yang berperikemanusiaan atau disebut juga nationalisme, yaitu bangsa yang hidup bersama dalam kekeluargaan Bangsabangsa. Socio-Democratie adalah merupakan gabungan dari sila demokrasi dan kesejahteraan sosial atau Keadilan Sosial. Jadi, faham demokrasi yang dianut adalah demokrasi atau persamaan seluruh rakyatnya, Negara-negaranya baik dalam lapangan politik, sosial, ekonomi, kebudayaan, maupun agama. Dan kesemuanya itu harus dijiwai oleh Sila ke-Tuhanan Yang Maha Esa. Perasan atau singkatan Pancasila ini menunjukkan, bahwa tiap-tiap sila dari Pancasila yang diusulkan Bung Karno itu tidaklah berdiri sendiri-sendiri terlepas satu sama lainnya, tetapi kelima unsur-unsur dari Pancasila itu merupakan satu rangkaian kesatuan yanag bulat. Selanjutnya, Bung Karno menawarkan lagi kepada sidang, barangkali sidang tidak setuju/senang kepada Tri Sila, maka Tri Sila diperas lagi menjadi satu. Sebagaimana telah dikemukakan tadi, kita mendirikan negara Indonesia yang kita semua harus mendukungnya, bukan dari satu orang atau satu golongan, tetapi Indonesia buat Indonesia, semua buat semua. Jadi yang lima diperas menjadi tiga dan yang tiga diperas menjadi satu, maka dapatlah satu perkataan Indonesia tulen, yaitu perkataaan "Gotong-royong" Negara Indonesia yang kita dirikan haruslah negara gotong-royong.

Gotong-royong adalah faham yang dinamis, menggambarkan satu usaha, satu amal, satu pekerjaan, satu karya, satu gawe bersamasama. Gotong royong adalah pembantingan tulang bersama, keringat bersama, perjuangan 
bantu-membantu bersama. Amal semua kepentingan semua, keringat semua buat kebahagian semua. Holopis-kuntul baris buat kepentingan bersama. Dan itulah yang disebut Gotong-royong. Ekasila yang berisi azas, prinsip gotong-royong ialah mendirikan negara gotong royong, satu buat semua, dan semua buat satu, serta semua buat semua.

Satu buat semua artinya mendirikan satu negara, bukan banyak negara, negara-negara bagian misalnya. Satu artinya satu negara kesatuan Indonesia, "buat semua" artinya untuk semua rakyat, seluruh rakyat Indonesia tanpa kecuali, tidak pilih kasih, tidak boleh membedabedakan. "Semua buat satu", artinya "semua" adalah seluruh rakyat Indonesia tanpa kecuali wajib bekerja, berjuang bersama untuk kepentingan, "buat satu", artinya untuk satu negara Indonesia. Bukan untuk satu orang, satu golongan atau satu kelompok manusia yang sedang memegang kekuasaan (pemerintah). Sedang istilah "semua buat semua", artinya jelas, kita semua tanpa kecuali mendirikan satu negara Indonesia bersama-sama didukung oleh semua golongan, kemudia kepentingan kita semua, menjadi perumahan bersama Indonesia buat Indonesia.

Kemudian, Bung Karno mempersilahkan kepada sidang untuk memilih, mana yang disepakati bersama, apakah Pancasila, Trisila, atau Ekasila?. Diperingatkan kepada hadirin bahwa disaat menyusun dasar-dasar filsafat Indonesia Merdeka itu, kita hidup di dalam masa peperangan. Di masa-masa peperangan itulah kita mendirikan Negara Indonesia, di dalam gunturnya peperangan, Beliau mengucapkan syukur Alhamdulillah kepada Alloh Subhanahu wata'ala, bahwa kita mendirikan Negara Indonesia bukan di dalam sinarnya bulan purnama, tetapi di bawah palu godam peperangan dan di dalam api peperangan. Timbulah Indonesia Merdeka yang demikian itu adalah Negara Indonesia yang lambat laun menjadi kuat.

Bung Karno, sekali lagi menyatakan keyakinannya, sesuai dengan usul-usul beberapa anggota barangkali perlu diadakan "noodmatregel" peraturan yang bersifat sementara. Tetapi dasarnya, isinya Indonesia yang kekal abadi menurut pendapat beliau haruslah Pancasila, namun terserah kepada sidang, usul itu diterima atau tidak, terserah. Beliau sendiri mengisyafi, bahwa tidak ada satu cita-cita, satu filsafat, satu Weltanschaung dapat menjelma dengan sendirinya, menjadi realitet, menjadi kenyataan jika tidak dengan perjuangan. Janganlah Weltanschung yang diadakan oleh manusia, janganpun yang diadakan oleh Hitler, oleh Stallin, oleh Lenin, atau oleh Sun Yat Sen, "De Mensch" manusia harus perjuangkan itu. Tanpa perjuangan, manusia itu tidak akan menjadi realitet bahkan, lebih dari itu : zonder perjuangan manusia tidak ada satu hal agama, tidak ada cita-cita agama yang dapat menjadi realitet. Janganpun buatan manusia seperti filsafat, Weltanschaung, seperti Pancasila itu, sedangkan perintah Tuhan yang tertulis dalam Kitab Suci Al-Qur'an, zwart op wit (hitam di atas putih) tidak dapat menjelma menjadi realitet zonder perjuangan manusia yang dinamakan umat Islam. Begitu pula perkataanperkataan yang tertulis dalam kitab Injil, cita-cita yang termasuk di dalamnya tidak dapat menjelma zonder perjuangan umat Kristen.

Maka dari itu, jikalau bangsa Indonesia ingin supaya Pancasila yang saya usulkan itu menjadi satu realitet, yaitu jika kita ingin hidup menjadi satu bangsa, satu nationalitet yang merdeka, ingin hidup sebagai anggota dunia yang merdeka yang penuh dengan perikemanusiaan, ingin hidup diatas dasar permusyawaratan, ingin hidup sejahtera dan aman dengan ke-Tuhanan yang luas dan sempurna, jangan lupa syarat untuk menyelenggarakannya, ialah perjuangan, dan sekali lagi perjuangan.

Jangan mengira bahwa dengan berdirinya negara Indonesia Merdeka itu perjuangan telah berakhir. Dalam Indonesia merdeka itu, perjuangan kita harus berjalan hanya lain sifatnya, coraknya dengan perjuangan. Sebagai negara yang bersatu, berjuang terus menyelenggarakan apa yang kita cita-citakan di dalam Pancasila. Bung Karno mengakhiri pidatonya dengan menegaskan bahwa "Indonesia" hanya bisa merdeka, jika bangsa Indonesia berani mengambil resiko dengan jiwa berkobar-kobar, dengan tekad "Merdeka", sekarang ini juga, "Merdeka atau mati".

Apabila kita baca hasil "stenografi verslag" Nampak jelas, bahwa usul Bung Karno secara keseluruhan mengenai Pancasila pada prinsipnya mendapat sambutan baik dari sidang BPUPKI. Tetapi, usul yang ditawarkan kepada sidang yaitu Pancasila sebagai "dasar filsafat Negara Indoneisa Merdeka" itu, pada tanggal 1 Juni 1945 tidak mendapat kesepakatan yang bulat dari sidang BPUPKI.Baik usul Bung Karno dan usul Mr. Muhammad Yamin, maupaun usul 
golongan Islam sebagai prasaran atau bahanbahan mentah itu diperdebatkan, diolah, digodog lebih lanjut oleh sidang sehingga "matang" kemudian dirumuskan, sehingga nanti nampak kesempurnaan.Setelah melakukan beberapa kali persidangan dan melalui perdebatan yang panjang akhirnya dapat dirumuskan dasar-dasar negara RI, maka tugas BPUPKI selesai kemudian pemerintah Jepang membentuk PPKI yang bertugas mempersiapkan segala sesuatu yang berkaitan dengan kemerdekaan Indonesia.

\section{Sidang BPUPKI}

Sidang BPUPKI yang kedua dilaksanakan pada tanggal 10 Juli sampai 17 Juli 1945 bertempat di gedung Pejambon Jakarta, dimulai pukul 10.00. sidang dibuka oleh ketua BPUPKI Dr. Radjiman Widiodiningrat, dengan terlebih dahulu memperkenalkan anggota baru yaitu : Abdul Fatah, Asikin Natanegara, Surio Hamijoyo, Mohammad Noor, Tuan Besar Abdul Kaffar. (Mohammad Yamin, 1965:145).

Sidang hari pertama dilaksanakan pada tanggal 10 Juli 1945 yang dipimpin langsung oleh ketua BPUPKI yaitu Dr. Radjiman Widiodiningrat. Diakhir persidangan hari pertama dilakukan pembentukan tiga panitia kerja, pertama, panitia untuk merancang Undang-undang Dasar, kedua, panitia untuk mempelajari hal pembelaan tanah air dan ketiga panitia untuk mempelajari hal keuangan dan perekonomian. Susunan ketiga panitia tersebut adalah:

a. Panitia Perancang Undang-undang dasar.

Ketua : Ir. Soekarno

Anggota :

1) R. Otto Iskandar Dinata

2) B.P.H. Porboyo

3) Haji Agus Salim

4) Mr. Achmad Subardjo

5) Prof. Dr. Mr. Supomo

6) Ny. Maria Ulfah Santos

7) K.H. Wahid hasyim

8) Parada harahap

9) Mr. J. Latulahari

10) Mr. Susanto Tirtoprodjo

11) Mr. Sartono

12) Mr. K.P.R.T. Wongsonegoro

13) K.R.T.H. Wuryaningrat

14) Mr. R.P.Singgih

15) Mr. Tan Eng Hoa

16) Prof dr. P.A. Husein Djayaniningrat

17) Dr. Sukiman Sirosandjoyo

18) Mr. A.A maramis
19) Tuan Myano

(Ismaun, 1981:147).

b. Panitia Perancang Bagian Pembelaan Tanah Air.

1) Abikusno Tjokrosujoso Ketua merangkap anggota

2) Abdul Kadir

3) Asikin Natanegara

4) P.H. Bintoro

5) Mr. B. Hendratono

6) Abdul Kaharmuzakar

7) H. Achmad sanusi

8) R. Asharsutedjo Moenandar

9) Mr. Samsudin

10) Mr. Sukardjo Wiropranoto

11) R.M.T.A. Soeryo

12) Abdul Kaffar

13) K.H. Maskur

14) K.H. Abdul halim

15) R.A.A. Sumitro Kolopaking

16) R. Sudirman

17) R. Aris

18) Mohammad Noor

19) R. Abulrahim patalykrama

20) Liem Koen Hian

21) Dr. R. Buntaran Martomojo

22) Ruslan Wongsokusumo

23) Ny. Sunaryo

24) Tuan Tanaka Anggota istimewa.

(Ismaun 1981:148)

c. Panitia Perancang Ekonomi dan Keuangan

1. Drs. Muhammad Hatta sebagai Ketua merangkap anggota

2. Ir. R.M.O. Soerahman Tjokroadisoerio

3. R.M. Margono Djojohadikusumo

4. M. Sutardjo

5. Dr. Samsi

6. Prof Ir. Roeseno

7. P. Soerjohamidjojo

8. Ki Hadjar Dewantoro

9. Dr. R. Koesoemah Atmadja

10. A.M. Dasaad

11. Oei Tjiong hauw

12. Prof Dr. Djenal Asikin Widjaja kusumah

13. P.F. dahler

14. Mr. Muhamad besar

15. Mr. Muhammad Yamin

16. A. Baswedan

17. Ki bagus Hadikusumo

18. Mr.R. Sastromujono 
19. Abdul fatah

20. K.H. Mas mansyur

21. Oe Tjang Tjoei

22. R.A.A wiranatakusumah

23. Mr. R. Suwandi

24. Tuan Tokonami Anggota istimewa. (Ismaun 1981:147-148).

Bahasan pertama dalam Persidangan kedua BPUPKI adalah mengenai bentuk negara. Hasil pemunggutan suara untuk menunjukan bentuk negara lain menunjukan 55 menyetujui bentuk negara Republik, 6 suara memilih kerajaan, 2 suara memilih lain-lain dan 1 suara blangko.(Muhammad Yamin, 1965:184).

Mengenai wilayah Indonesia sebagian besar menghendaki bekas wilayah Hindia Belanda ditambah dengan Malaya, Borneo Utara, Papua Nugini dan Timor portugis. Persidangan ini membahas pula berkenaan dengan penyusunan undang-undang Dasar, susunan pemerintahan dan bentuk negara antar unitarisme dan federalis.

\section{PENUTUP}

\section{Simpulan}

Dalam masa sidang BPUPKI tanggal 29 Mei sampai 1 Juni 1945 merupakan babak Perancang. Beberapa pembicara yang mengemukakan prasaran atau pendapat diantaranya merupakan anggota "braintrust", seperti Mr. Muhammad Yamin, Ir. Soekarno, Prof. Dr. Mr. R. Soepomo dan lain-lain. Mr. Muh Yamin menyampaikan prasarannya tentang "Azas dan Dasar Negara Kebangsaan Republik Indonesia", juga usul mengenai batas-batas wilayah Indonesia yang akan merdeka meliputi tanah tumpah darah nusantara warisan sejarah zaman Majapahit.

Ir. Soekarno mengusulkan dasar Negara yang diberi nama Pancasila dengan meletakkan sila kebangsaan terlebih dahulu. Sedangkan Prof. Dr. Mr. R. Soepomo mengemukakan teori Negara dan syarat-syarat bedirinya negara serta prinsip-prinsip negara dan pemerintahan. Dalam masa sidang kedua BPUPKI tanggal 10 Juli sampai 17 Juli 1945 ialah merupakan Babak Perumusan yang berhasil merumuskan "rancangan dasar negara dan hukum dasar", yakni Piagam Jakarta sebagai Mukadimah, Hukum Dasar, Naskah Pernyataan Indonesia Merdeka, sehingga pada tanggal 17 Juli 1945 semua rancangan Hukum Dasar Negara Indonesia Merdeka selesai.

Dari uraian diatas dapat kita ketahui, bahwa tujuan pembentukan BPUPKI oleh pemerintah Jepang, yaitu hanya menyelidiki usaha-usaha persiapan kemerdekaan namun kenyataan sebenarnya ialah "Merancang Undang Undang Dasar Indonesia yang merdeka dan berdaulat". Kiranya dapat dipahami bahwa BPUPKI yang mewakili seluruh bangsa Indonesia benar-benar mengambil nasibnya ditangan sendiri untuk menentukan persiapan kemerdekaannya, artinya tidak menurut saja kepada ketentuan Juridis formil dan keinginan kolonialis Jepang.

\section{DAFTAR PUSTAKA}

Asmawijaya. 1997. Proses Persidangan BPUPKI Dalam Merumuskan UUD Negara Indonesia. Jakarta : Media Press

Haryono, Anwar. 1997. Perjalanan Politik Bangsa Indonesia : Menoleh Ke Belakang Menatap Masa Depan. Jakarta : Gema Insani.

Ismaun. 1984. Diktat Pengantar Ilmu Sejarah. Bandung: IKIP

Kansil, C.S.T. 1968. Sejarah Perjuangan Pergerakan Kebangsaan Indonesia. Jakarta: Erlangga

Lembaga Soekarno-Hatta. 1984. Sejarah Lahirnya UUD 1945 dan Pancasila. Jakarta : Idayu-Press.

Noer, Deliar. 1987. Partai Islam di Pentas Nasional. Jakarta : Graffiti.

Notonagoro. 1963. Beberapa Hal Mengenai Falsafah Pancasila. Jakarta: C.V. Pantjuran Tudjuh.

Notosusanto, Nugroho. 1971. Naskah Prokalamsi yang Otentik dan Rumusan pancasila yang Otentik. Departemen Hankam,Pusat Sejarah ABRI.

Poesponegoro, Marwatidjuned. et.al. 1975. Sejarah Nasional Indonesia Jilid VI. Jakarta : Balai Pustaka

Pringgodigdo, A.K, H. 1964. Sejarah Pergerakan Rakyat Indonesia, Jakarta: Pustaka Rakyat.

Ridhwan Indra, Moh. 1978. Peristiwa-peristiwa di Sekitar Proklamasi 17-08-1945. Jakarta: Sinar Grafika.

Rutgers, S.J. 1951. Sejarah Pergerakan nasional Indonesia, Surabaya: C.V. Hayam Wuruk 
Saifuddin Anshari, H. Endang. 1981. Piagam Jakarta 22 Juni 1945. Jakarta: C.V. Rajawali

Sihombing, O.D.P. 1962. Pemoeda Indonesia Menentang Fasisme Djepang, Jakarta: Sinar Djaja.

Soebardjo Dj., Ahmad. 1977. Lahirnya Republik Indonesia. Jakarta: PT.Kinta.

Soekarno. 1960. Pancasila Dasar Filsafat Negara. Kursus Bung Karno, Jakarta: Yayasan Empu Tantular.

Sunoto. 1981. Pancasila: Pendekatan Melalui Sejarah dan Pelaksanaanya, Yogyakarta: Hanindita

Suharsimi, Arikunto. 1998. Prosedur Penelitian, Suatu Pendekatan Praktik: Reneka Cipta

Surachman, Winarno 1998. Pengantar Penelitian Ilmiah. Bandung: Tarsito

Wilhem, Donald. 1980. Indonesia Bangkit, Jakarta : UI Press.

Yamin, Muhammad. 1959. Naskah Persiapan UUD 1945. Jakarta: Yayasan Prapanca. 
Jurnal Artefak:

History and Education, Vol.4 No.2 September 2017

Halaman | 118 